Nabieva V. The notion of the ideal king in Mary Stewart's pentalogy

\author{
UDC 82 \\ DOI https://doi.org/10.24919/2308-4863/36-2-24
}

Vusala Farhad NABIEVA, orcid.org/0000-0002-2236-9170

Dissertator at the Department of World Literature and Comparative Studies Institute of Literature Nizami Ganjavi of National Academy of Sciences of Azerbaijan (Baku,Azerbaijan) paradiseaegis@gmail.com

\title{
THE NOTION OF THE IDEAL KING IN MARY STEWART'S PENTALOGY
}

Mary Stewart, one of the most famous writers of the XX century, distinguishes with her writing style, and at the same time masterfully focuses the attention of readers on topics that form the basis of her novels. Before writing "Arthur pentalogy", the author wrote many novels in the romantic suspense subgenre and gained the love of readers. Mary Stewart had been familiar with both historical and archaeological sources for many years before writing this legendary subject and clearly described the spirit of the time in Pentalogy. At the age of 53, she published the first part of the pentalogy "The Crystal Cave". As a result of the success of this work, the other parts of the pentalogy began to appear.

The fifth century AD entered British history as the "dark ages" and was remembered with the legendary warrior King Arthur. Legends are the embodiment of the thoughts, desires, and spirit of the people. This legend about Arthur, acting in the dark and distant Times, tells of the ruler, leader, and redeemer of the people. In those distant times, people were just simply tried to survive, and it was at that time when the legendary Arthur appeared in the political arena, but his power did not last long. Maintaining the literary traditions of "Arthuriana", the writer tries to show not only the ideal king but also the process and the pangs that King Arthur passes throughout his life. Here readers observe a person who struggles not just with the outward things but with his inner world too.

In Mary Stewart's ideal leader concept, King Arthur is portrayed as a skillful and just commander who unites the country and the people. Arthur constantly tries to take care of his family, friends, associates. His humanism is boundless, and this feature only harms him. The difficulties and betrayal that the King faced in his life turned him into a wise man. The lack of freedom of ordinary people in his life and the burden of his higher mission limits his freedom of behavior. In Pentalogy, the writer revives the character of the king, who accepted his fate without rebellion.

Key words: Mary Stewart, heroism, psychological state, the burden, self-control.

Вюсаля Фархад НАБІЕВА, orcid.org/0000-0002-2236-9170

дисертант відділу світової літератури і компаративістики Інституту літератури імені Нізамі Гянджеві Начіональної академії наук Азербайджану (Баку, Азербайджан) paradiseaegis@gmail.com

\section{ПОНЯТТЯ ІДЕАЛЬНОГО КОРОЛЯ В ПЕНТАЛОГІЇ МЕРІ СТЮАРТ}

Одна із відомих письменниць ХХ століття Мері Стюарт відрізняється своїм стилем письма, а також майстерно направляє увагу читачів до тем, щчо складають основу ї̈ романів. Письменниця, до того, як створити «Артуровську пенталогію», написала багато романів в субжанрі романтичного саспенсу та завоювала любов читачів. Мері Стюарт, до того, як освітити ияю історично-легендарну тему, роками знайомилась з історичними та археологічними джерелами та детально описала в пенталогї̈ настрій цієеї епохи. Коли літератору було 53 роки було видано перший роман пенталогіi “Тhe Crystal cave”. Внаслідок успіху цьвого твору були видані інші ї̈ романи.

П'яте століття нашої ери в Британії було «темною епохою» та запам'яталося епохою легендарного вождя Короля Артура. Легенда є втіленням думок, бажань та настрою народу. А в легенді про Артура відображається майстерний правитель, лідер та спаситель народу, який жив у изей темний та далекий час. У ицей далекий час втомлений народ тільки виживав, й саме в цей час на політичній арені з'явився Артур, але його влада продовжувалася недовго. Письменниия, яка зберігала літературні традииіі “Arthurian”, намагається створити не тільки ідеального короля, у ицей же час вона намагається показати його життєві переживання. Тому читачі бачать не тільки подї, які відбуваються біля нього, але й людину, яка бореться зі своїм внутрішнім світом.

У кониепиії ідеального лідеру Мері Стюарт Артур відображається як майстерний та справедливий вождь, щцо об 'єднує свою краӥну та свій народ. Артур постійно піклується про свою родину, друзів, приятелів. Його гуманізм безкрайній, але ия риса його характеру наносить шкоду лише йому самому. Труднощі, зрада в його житті створили із нього мудру людину. Свобода, яка була у простих людей, але не була у нього та вантажність його вищої місії обмежує свободу його поведінки. В пенталогї письменниця відображає характер короля, щчо покірно приймає свою долю.

Ключові слова: Мері Стюарт, героїзм, психологічний стан, тягар, самоконтроль. 
Formulation of the problem. Mary Stewart, who began her professional career due to her husband's encouragement, Professor of Geology Frederick Henry Stewart, ended her career with the death of her husband. Her first professional work, "Madame, Will You Talk?", was published in 1955. The writer was 39 years old at that time. Even though she was the beginning of a somewhat dangerous and mysterious creative path in terms of her age, the power of her talent and heroes crowned her with the title of a writer loved and selected by readers. Stewart, who was not a one-sided writer, would write her works that would suit the interests of her readers, even children. Her works were awarded valuable prizes, screened, and almost all of her works became bestsellers. The author's works have been translated into Russian, Slovak, Portuguese, Icelandic, German, French, Dutch, Finnish, Hebrew, and other languages.

The aim of the research - to identify the ideal features of the king in Mary Stewart's pentalogy.

Presenting main material. Issues of Arthuriana: steps to success. Mary Stewart's creativity is highly appreciated not only by readers but also by critics. Professor, literary critic Frederick William John Hemmings writes: "no wonder that Mary Stewart should be accounted 'very successful'. It is success well-earned, for there is nothing cheap in the writing and nothing machine-made in the devising." (Daniel Jones, 1998: 380) The reason for these words is that the writer had an innate talent. The writer's pen shows that she was gifted from birth. Her first poem, "Teeth", was published in 1921 when she was just five years old. The writer expresses herself as follows: "I am first and foremost a teller of tales, but I am also a seriousminded woman who accepts the responsibilities of her job, and that job, if I am to be true to what is in me, is to say with every voice at my command: 'We must love and imitate the beautiful and the good.' It is a comment on our age that one hesitates to stand up and say this aloud." (Tracey Watson, 2005: 379)

Each period has its characteristics and each nation or tribe has its heroism or defeats. All of these are delivered to us through legends, tales, folklore, written sources, authors' works, or archeological excavations that have traveled for centuries. In general, people's interest in history is undeniable, as is their interest in the future. It is based on historical facts that writers use their imagination to revive them and convey their human feelings, sins, betrayals, loyalty, and passions to people in a more interesting way through the filter of centuries. All these concepts build a spiritual bridge between the past and the future and describe the supremacy and abomination of the actions that people face in time and constantly, as they begin to rise.
Events and mysteries that interest everyone sometimes leads to the consecration of the unknown or the creation of people, heroes, or beings with supernatural powers. There are also images of heroes that people find most comfortable with. The heroic characters have always interested readers a lot. The reason for this is that when people read books of this style, they are inspired by the positive deeds of the protagonist, or they combine what they want to do, their dreams, or what they cannot realize through these images. Despite benefiting from the same work, everyone's heroes are different because everyone's thoughts, views, and values are different. Even when readers come together, they argue about the merits of the hero, even though they talk about the same heroes. This is because people have idealized notions of what they want to see or what they cannot see in real life.

Sometimes any name or country makes a special positive or negative impression on us. Arthur's name is just like that. When we hear his name, we imagine a brave, courageous, fearless, far-sighted person in our mind. Whether Arthur is a mysterious and enigmatic historical or a legendary figure has always attracted everyone's attention. Historians still have endless speculations as to whether Arthur was a real historical figure or by what name he had existed. In fact, the main issue is not whether he really existed, but the notion of a fair ruler who worked for his people's prosperity.

There is a widespread term in the literature, the term "Arthurian" or the term "Arthurian literature". This notion is exactly like that in the Oxford dictionary. "Arthurian [a: $\theta j$ jorrın] connected with the stories about Arthur, a king of ancient Britain, his Knights of the Round Table and court at Camelot: Arthurian legends." (A.S Hornby, 2005: 72) Different lectures are held at universities on this topic. Arthurian dictionaries are compiled, sites on the Internet are set up, performances are played, films and cartoons are made, companies are created, streets are named after him, and King Arthur's Community School was established in England in 1958. In 2019, King Arthur's Community School was established, then it was renamed Arthur's School.

When we look at the literature history, we obviously notice the interest in King Arthur. Geoffrey Ashe, a British historian and author of many books on King Arthur, described the subject as follows: "Arthur's history is more than just a medley of yarns, more than just a saga in the "dream time" of myth. It puts him within a definite period. It names definite places, and takes him to definite countries. All the further legend-weaving presupposes this history. Romancers add to it and enlarge it; they change its 
emphasis and the order of events; they draw in matter from other sources, sometimes to a point where they lose sight of it. But in substance they accept it. Their own stories assume it as a backdrop, and fit, more or less, into the scene structure it creates." (Geoffrey Ashe, 1985: 3) At the heart of all these stories stand religious beliefs, courage, justice, peace, unity, equality, brotherhood, incest, betrayal, passion, sin, death, strong ruling, kindness, and so on. Although it is known to every one according to the subject, King Arthur, his period and, the concept has always been appreciated by readers.

Works about King Arthur and his period began to be written by male authors. Examples include Gildas' "De Excidio at Conquestu", Geoffrey of Monmouth's "Historia Regum Brittaniae", Thomas Malory's "Le morte d'Arthur", John Steinbeck's "Acts of King Arthur and His Noble Knights", etc.

Women writers have also successfully addressed this topic. Here we can mark Marie de France "Lanval", Dinah Maria Mulock Craik "King Arthur: Not a Love Story", Jessie Weston "Knights of King Arthur's Court", Rosemary Sutcliff "The King Arthur trilogy", Marion Zimmer Bradley "The Mists of Avalon" and many valuable women writers can also be listed.

Features of the artistic representation of the image of King Arthur. The main plot of King Arthur's stories is that Arthur was born out of the destructive relationship between King Uther Pendragon and Duchess Igerne, lived away from his family for many years without knowing who he was, pulled the Excalibur sword out of stone before becoming king, created round table knights and fought against the Saxons, his marriage to the young and beautiful Guenevere, and rumors about his wife betrayal with Lancelot, one of Arthur's knights, the birth of Arthur's nephew and son Mordred and consequently Mordred's fatal wounding of Arthur.

Stewart wanted to deal with historical issues a long ago. As a result, she wrote "The Crystal Cave". This novel was published in 1970. By this time, the author had already published 10 successful works, and therefore the publishers did not pay much attention to the publication of this work, as the writer changed the genre. However, this work was a great success and was included in the list of best-selling books. The success of the writer is that she used her rich and diverse creative potential to portray the vast possibilities created by the legends of King Arthur in her own way.

The writer was interested in the history of the people, traveled to historical places and, got acquainted with interesting information. As can be seen from her works, the smooth flow of history stems from the fact that the author's spouse, Frederick
Henry Stewart, was a prominent geologist. The deep knowledge of her spouse allows her to focus on the historical subject. Then, in 1973, she published her second historical work, "The Hollow Hills". In 1979, she completed "The Last Enchantment", completing the Merlin Trilogy. In 1983, she wrote "The Wicked Day", and finally in 1995, she completed her pentalogy with "The Prince and the Pilgrim". In fact, Stewart did not intend to write a trilogy or pentalogy when she first set out on a historical subject. She said in an interview with Raymond H. Thompson for The Camelot Project: "The point was that when I wrote each book it was to be the last. When you do that, you lay some traps for yourself. You kill off people you wish you hadn't killed off; you keep people alive that you don't want; and you turn them in the wrong direction, as it were, which can be darned awkward if you want to go on with the story." (Interview 1989) Maybe the attractiveness of the pentalogy comes from the factor that she created the whole complete book separately without the intention to write next.

Mankind has gone through many historical trials to this day. Each period has its own set of signs. The period when Mary Stewart addressed the subject of history coincides with the 1970s. Characteristic of these years, the chaos in Britain is characterized by differentiation, economic stagnation, gender problems, racism, and so on. All these problems manifested themselves sharply in people and created a situation of moral crisis. "The 1970s may be considered 'lost' in a number of ways. Firstly, intense feelings were produced by the radical social changes of the period, and such social and emotional trauma is often unsettling to reproduce or recall. $<\ldots>$ Secondly, the personal hardships endured make it a decade which many people would prefer to forget." (Laurel Forster, 2010: 1-2) From a literary point of view, the period is a source of nourishment for the writer, and light on the situation, either completely or partially.

Racial discrimination reigns in almost all major powerful countries and that dominance was evident even in well-off immigrants. Russian literary critic Valentina Vasilyevna Ivashova describes those years as follows: " $<$... $>$ How are you today, England? And where does historical destiny lead you? This question began to be asked by some British authors <...> What are the peculiarities of the English national character, "Englishness" that has distinguished the English for a century? Sometimes it is about "Englishness" (excluding the Scots, Welsh, and even more so the Irish), but often "Englishness" was applied to all the peoples of Great Britain. It is not for nothing that the British are increasingly using the term "British", "British" instead of "English", "Englishman" more and more persistently." (Ivasheva, 1988) 
Mary Stewart, known as one of the true patriots, can be seen in her attitude to the term "Englishness" in her historical works. Portraits of Arthur, the legendary and suspicious historical leader of the Celts, and his warriors show the identity of real landowners in Britain. "In contemporary vernacular, the term "Briton" would seem to allude to all the people of the British Isle; however, in the British Isle of the first millennium $\mathrm{AD}$, the appellation "Briton" referred to native Celtic people who inhabited the island before the Romans and Anglo-Saxons." (Laura Cooner, 2008: 17) At that time, more than people, the era itself needed a hero. On the one hand, the endless claims of the Saxons occupying Britain for the lands of the Celts, and on the other hand, the attacks of the Picts, the Irish, and the Anglos kept the country under tension. Against the background of all these historical events, King Arthur, as noted in the V-VI centuries $\mathrm{AD}$, fearlessly fought against the invaders on the British island of Celtic territory and ensured the safety of his folk. The author introduces King Arthur as one of the main characters in the novels of pentalogy "Hollow Hills", "The Last Enchantment" and "The Wicked day".

Arthur's name is not unambiguously explained by scholars. All these theories are the result of extensive researches. "E.W.B.Nicholson regards Arthur as a combination of two Celtic words: artos ("bear") and viros ("man"), which would make Arthur's name a metaphor for a strong warrior: "Bear-Man." A.Holder proposed a connection with the Irish art ("stone"), and M.Müller tried to link Arthur to a culture-divinity in part by noting that the Aryan term for "to plough" is ar (Bruce, 4n)." (Christopher W., 1999: 37) There are writers who accept these theories. Mary Stewart also agrees that Arthur's name is of Celtic origin.

"The ancient Celts had a special role for the king. He not only possessed indisputable political and economic power but was also a kind of mystical symbol of the prosperity of his country and nation." (Anisimov, 2010: 136) This Celtic notion of a king allows even rulers who abuse their position to be justified. However, this concept is completely united in the example of Arthur. Arthur, created by Stewart, is a portrait of the supreme king, who improves the living conditions of his people, creates the principle of equality, and does not violate the laws.

The author wrote the first novel of the pentalogy, "The Crystal Cave", about Merlin, known as the magician of the period. Merlin is described from her childhood to adolescence. He is described as intelligent, with special abilities, and events are narrated through his own language. He is portrayed as Arthur's cousin. In this novel, The Future King, who will unite Britain, is narrated by Merlin. " $<\ldots>$ a King $<\ldots>$ whose name will be a shield and buckler to men until this fair land, from sea to sea, is smashed down into the sea that holds it, and men leave earth to live among the stars." (Mary Stewart, 1989: 357) "The Crystal Cave" is distinguished by the writer's lack of traditional historical facts and the prominence of her imagination.

"The Hollow Hills" is a continuation of "The Crystal Cave". Here again, the events are narrated by Merlin. King Arthur's being given to Merlin for safety since his infancy is described as living far away from his family without knowing who he was until the sword Caliburn had been pulled out by him. Arthur's illegitimate half sister, Morgause (of the same father but a different mother), spends a night enchanting him so as not to banish from the kingdom after her father's death, even though he doesn't know who he is. Unaware of his identity, Arthur became a victim of incest. As a result of this night, Morgause became pregnant according to the plan and a child named Mordred would be born.

Elements of Stewart's desire to write about Roman-dominated Britain are reflected in a pentalogy. The author describes Merlin, Arthur, Ambrosius, and Uther Pendragon as the descendants of the Roman emperor Magnus Maximus, who lived in the IV century. In "The Hollow Hills", one of Merlin's main objects of the search is Maximus' sword. This sword will be the famous sword that Arthur will pull out of stone, Caliburn (the sword that everyone knows as Excalibur). "It is a sword for the High King of Britain, and was made to defend Britain against her enemies" (Mary Stewart, 1996: 298)

Stewart shares with the reader the specific features of the century, the positive, negative, and human aspects of historical and legendary personalities, and in this case, it is impossible not to be impressed by the writer's heroes. This is how the prominent professor Maureen Fries evaluates Arturiana "written by M. Stewart's narration is associated with an analysis of the inner world of the heroes, and not with a simple description of their many adventures, which are the external aspects of the Arthurian legend." (Shiryaeva, 2008: 99). The writer sincerely conveys the inner world of his characters, their experiences and, human qualities. In this pentalogy, we can see the revival of Merlin, Arthur, Ambrosius, Uther Pendragon, Igerne, Bedwyr, Guenevere, Morgan, Morgause, Mordred, and others. The author skillfully describes the reasons or weaknesses of people, even those who go astray by their speech of her characters, without blaming them, and sometimes with her own justification.

In "The Last Enchantment", Merlin owed himself to tell the story of what he had seen thanks to an already running out of the gift to King Arthur. "Bedwyr your 
friend, and Guinevere you Queen, love one another." (Mary Stewart, 1984: 352) After this news, the expressionlessness on Arthur's face surprised Merlin.

"You knew?"

"Yes," he said, quite simply, "I know." There was a pause, while I looked for words and found none. He smiled. There was something in the smile that did not speak of youth or power at all, but of a wisdom perhaps greater, because more purely human, than is ascribed to me. "I do not have vision, Merlin, but I see what is before my eyes." (Mary Stewart, 1984: 352) During the conversation, it appears that Arthur is aware of his long-lasting love affair with his wife, Guenevere, and his childhood friend, Bedwyr. It was Arthur's second marriage to Guenevere. He also had his first marriage to a girl named Guenevere. She and the baby died during giving birth. It was a difficult time for Arthur. He remarried because of a new heir to the kingdom, but this marriage brings him nothing beyond loneliness and unhappiness. Realizing all this, King Arthur tries to find harmony in his inner relationship and himself. At the same time, Arthur realizes that Bedwyr and Guenevere are the victims of their feelings. "she is a queen, and childless, so her life must be less than a woman's. $<\ldots>$ She is young, and she has a girl's needs, of companionship and of love." (Stewart, 1984: 353-354) The pains of life had made him a wise man. Of course, this attitude of Arthur is not unequivocally accepted by many people. Many issues depend on presenting the action, when you read a work, you see that everyone has their own truth, and you understand the psychological state of people rather than you blame.

Stewart, who captured the spirit of ancient times, has skillfully transferred that to the modern period. " $<\ldots>$ major motive, rooted in the distant past of the Celts, is the motive of chivalry, knight honor, loyalty, and comradeship. <...> And from the novels of M. Stewart, it is clear that King Arthur could retain power only with the help of reliable allies, loyal associates and a well-organized and trained army." (Anisimov, 2010: 136) Knighthood, a symbol of brotherhood and unity, ensured the prosperity of his country as a result of the guidance and justice of Arthur, the wise and far-sighted king.
When we read, we can easily feel Merlin's strong influence on Arthur and his respect and love for Merlin. Thanks to Merlin's foresight he warns that Arthur will be in mortal danger by his son Mordred. Arthur orders Merlin to kill the child to avert danger to himself and the kingdom. Merlin tells Arthur that he can do nothing against the will of the Gods. By killing infant Mordred, Arthur wanted to bury the sin he had committed in ignorance. Arthur: "And who am I to take on me yet again the wish for my son's death? Once was too much. God knows I paid for it." (Stewart, 1984: 452) Here we see Arthur suffering spiritually because of his negative thoughts. Stewart portrays Arthur not only as a skillful leader but also as a person with human hesitations.

Conclusions. "The Wicked Day" may not be called the heart of pentalogy. The inevitability of events, psychological tensions, and mental torments are the proofs on every page of the book. Arthur's late relationship with his son Mordred, the gap created by time, inevitably goes unnoticed. Arthur, who created the writer, represents both inner and physical strength, self-control, composure, peace, as well as human qualities.

"The historical trilogy by Mary Stewart is not a game of restoring the distant past. $<\ldots>$ The main thing in the Mary Stewart trilogy is not the personal grief of the king of the Britons $<\ldots>$ These ideals are a peaceful life in the land of the Britons, peaceful labor for which the young king is fighting with a sword in his hands. These ideals are based on a paradox: Arthur must strive for a peaceful life in flamy and deadly battles, but these battles are not for selfish purposes, but in the interests of the people, who recognized in Arthur their not only revered but also their beloved leader." (Ivasheva, 1989: 443) The writer's hero is a wise man who accepts the limitations of his responsibilities desperately, who understands the burden of his duty, and knows that responsibility is more important than feelings and thoughts. He came to this conclusion through conflicting ways of life. A high-minded king works only for the welfare of his nation, apart from his happiness. "I am a king, and my life is a king's" (Mary Stewart, 1984: 353).

\section{BIBLIOGRAPHY}

1. Daniel Jones, John D.Jorgenson (1998). Contemporary authors New Revision Series: Vol.59, publisher: Gale: Detroit, p:446

2. Tracey Watson (2005). Contemporary authors New Revision Series: Vol.130, publisher: Tomson Gale: Detroit, p:449

3. A.S Hornby, Sally Wehmeier, Ashby Michael (2005). Oxford Advanced Learner's Dictionary $7^{\text {th }}$ edition, Oxford University Press, p:1780

4. Geoffrey Ashe in association with Debrett's Peerage (1985). The Discovery of King Arthur. Anchor Press/Doubleday, Garden City, New York, p:226

5. Interview with Mary Stewart URL: https://d.lib.rochester.edu/camelot/text/interview-with-mary-stewart (date accessed:09.21.20) 
6. Laurel Forster and Sue Harper (2010). British Culture and Society in the 1970s: The Lost Decade. Cambridge Scholar publishing, p:310

7. Ивашева В. Стюарт М. Полые холмы. Последнее волшебство: Романы. Москва: Радуга. 1988. URL: http://www.fandom.ru/about_fan/ivasheva_1.htm (дата обращения: 08.19.20)

8. Laura Cooner Lambdin and Robert Thomas Lambdin (2008). Arthurian writers: a biographical encyclopedia, Greenwood Press, Westport, Connecticut, p:424

9. Christopher W. Bruce (1999). The Arthurian Name Dictionary. "Taylor\&Francis", p:504

10. Анисимов А. Б. Древнекельтские Мотивы в Артуровских романах Мэри Стюарт. ВЕСТНИК ЯГУ, 2010, том 7 , № 1, 135-137 c

11. Mary Stewart (1989). The Crystal Cave. New York: Fawcett Crest, p: 384

12. Mary Stewart (1996). The Hollow Hills, "Fawcett Columbine", p:518

13. Ширяева Ж. Л. Легенда о короле Артуре в английском романе XX века (на материале романов Т. Уайта и М. Стюарт) : дис. к. филол. наук. Воронеж : 2008. 171 с.

14. Mary Stewart (1984). The Last Enchantment. Fawcell Crest. New York, p:480

15. Валентина Ивашева (1989), Судьбы Английских Писателей. Москва, Советский писатель, 446 с.

\section{REFERENCES}

1. Daniel Jones, John D.Jorgenson (1998). Contemporary authors New Revision. Series: Vol. 59, publisher: Gale: Detroit, p. 446

2. Tracey Watson (2005). Contemporary authors New Revision Series: Vol.130, publisher: Tomson Gale: Detroit. p.449

3. A.S Hornby (2005), Sally Wehmeier, Ashby Michael. Oxford Advanced Learner's Dictionary 7th edition, Oxford University Press. p.1780

4. Geoffrey Ashe in association with Debrett's Peerage. The Discovery of King Arthur (1985). Anchor Press/Doubleday, Garden City, New York, p:226

5. Interview with Mary Stewart URL: https://d.lib.rochester.edu/camelot/text/interview-with-mary-stewart (date accessed:09.21.20)

6. Laurel Forster and Sue Harper (2010). British Culture and Society in the 1970s: The Lost Decade. Cambridge Scholar publishing. p:310

7. Ivasheva V. Stewart M. Poliye Xolmi. Poslednee volshebstvo: Romani [Stewart M. The Hollow Hills. The Last Enchantment: Novels]. M.: Raduga. 1988. URL: http://www.fandom.ru/about_fan/ivasheva_1.htm (date of access: 08.19.20) [in Russian].

8. Laura Cooner Lambdin and Robert Thomas Lambdin (2008). Arthurian writers: a biographical encyclopedia. Greenwood Press, Westport, Connecticut, p:424

9. Christopher W. Bruce. (1999). The Arthurian Name Dictionary. "Taylor\&Francis", p:504

10. Anisimov A.B. Drevnekeltskie motivy v arturovskikh romanah Meri Stewart [Ancient Celtic motifs in the Arthurian novels by Mary Stewart]. Vestnik YAGU (Vestnik of YSU), 2010, tom 7, № 1, 135-137 s [in Russian].

11. Mary Stewart (1989). The Crystal Cave. Fawcett Crest. New York. p:384

12. Mary Stewart (1996). The Hollow Hills, "Fawcett Columbine". p:518

13. Shiryaeva J.L. Legenda o korole Arture v anglijskom romane XX veka (na materiale romanov T. Uayta i M. Styuart) [The legend of King Arthur in an English novel of the 20th century (based on the novels of T.White and M.Stewart)]: Diss.....k. filol. nauk. Voronezh. 2008. 171 s. [in Russian].

14. Mary Stewart. (1984) The Last Enchantment. Fawcell Crest. New York, p:480

15. Ivasheva V. (1989) Sudbi angliyskikh pisateley [The fate of English writers]. M.: Sovetskij pisatel, 446 s. [in Russian] 